\title{
An introduction to the theological politico-ethical thinking of Koos Vorster
}

\author{
Authors: \\ Jan H. van Wyk ${ }^{1}$ \\ Nico Vorster ${ }^{1}$ \\ Affiliations: \\ ${ }^{1}$ School for Ecclesiastical \\ Sciences, North-West \\ University, South Africa \\ Correspondence to: \\ Nico Vorster \\ Email: \\ nico.vorster@nwu.ac.za \\ Postal address: \\ Faculty of Theology, PO Box \\ 20004, Noordbrug 2522, \\ South Africa \\ Dates: \\ Received: 23 Mar. 2011 \\ Accepted: 14 June 2011 \\ Published: 22 Oct. 2012 \\ How to cite this article: \\ Van Wyk, J.H. \& Vorster, \\ N., 'An introduction to the \\ theological politico-ethical \\ thinking of Koos Vorster', \\ In die Skriflig/In Luce Verbi \\ 46(1), Art. \#76, 10 pages. \\ http://dx.doi.org/10.4102/ \\ ids.v46i1.76
}

C 2012. The Authors. Licensee: AOSIS OpenJournals. This work is licensed under the Creative Commons Attribution License.
Koos Vorster had a productive career as theologian and published on a wide variety of subjects. However, he will especially be remembered for his contribution to political and social ethics. This article discussed his theological politico-ethical thinking. Firstly, this article examined his epistemology, with special reference to his revelational-historical approach, his hermeneutics, preference of deontological ethics and his renouncement of ethical absolutism, which characterises fundamentalist approaches to ethics. Secondly, it examined his views on Apartheid and the 'struggle' in the 1970s and 1980s. Vorster renounced Apartheid and pleaded for non-violent change brought about by an evangelical change of hearts and attitude that had to be accompanied with real efforts to address poverty and unjust structures. Finally, the article discussed his views on human dignity, human rights and relations between the state and religion, as well as his views on society and economics.

'n Inleiding tot die teologiese, politieke en etiese denke van Koos Vorster. Koos Vorster het ' $n$ besonderse produktiewe en vrugbare akademiese loopbaan gehad en oor ' $n$ verskeidenheid van onderwerpe gepubliseer. Hy sal egter veral onthou word vir sy bydrae tot politieke en sosiale etiek. Hierdie artikel ondersoek die teologies-polities etiese denke van Koos Vorster. Die eerste deel bespreek sy epistemologiese uitgangspunte, waaronder sy omvattende openbarings-historiese benadering, sy hermeneutiek, voorliefde vir ' $n$ deontologiese etiek, en sy afwysing van etiese absolutisme soos veral vergestalt in fundamentalistiese benaderings tot die etiek. Die tweede deel bespreek sy houding teenoor Apartheid en die 'struggle' in die 1970s en 1980s. Vorster het die vergrype van Apartheid geïdentifiseer en aangespreek, maar terselfdertyd geweldadige verset verwerp, en ' $\mathrm{n}$ evangeliese verandering van gesindhede bepleit wat gepaard gaan met die opheffing van onderdrukte gemeenskappe en ontbinding van onregverdige strukture. Die laaste deel van die artikel bespreek Vorster se sienings oor menswaardigheid, menseregte, die verhouding tussen kerk en godsdiens, asook sy siening oor die samelewing en die ekonomie.

\section{Introduction}

At the end of 2011, Koos Vorster retired as Professor in Ethics after a career of 21 years in full-time academy. He had a productive academic career in which he acquired a PhD and ThD, published 10 books and 80 articles and co-authored 18 articles. Amongst the journals in which he published are the Journal of Religious Ethics, Ecumenical Review, Journal of the Study of Religions and Ideologies, Journal of Reformed Theology, Hervormde Teologiese Studies, Acta Theologia, Evangelische Theologie and In die Skriflig. Vorster started his full-time academic career in 1990, when he was called as Professor in Church Polity to the Hammanskraal Theological School of the Reformed Churches in South Africa. From 1995, after the Hammanskraal Theological School and the Potchefstroom Theological School merged, he filled the chair of Professor in Church History. With the retirement of Prof. Paul de Bruyn in 1999, he became Professor in Ethics. During the period 1999-2010, he acted as Director of the School of Ecclesiastical Sciences. As Director he developed a research programme called Reformed Theology and the South African Society, in which he specifically contributed to a subproject on human rights and ethics. This project has thus far delivered 62 articles, a number of PhDs and four books. He also served as Rector of the Theological School of the Reformed Churches (2004-2007), editor of In die Skriflig and Studia Historiae Ecclesiasticae, and advisor of the International Association of Religious Freedom at the Human Rights Council in Geneva. Vorster became a rated researcher in 2005 and again received a rating from the National Research Foundation in 2010.

Although Koos Vorster wrote a great deal on ecclesiology, church polity, dogma-history, futurological tendencies in ministry and church history, he will mainly be remembered as a distinguished politico-theological ethicist who expounded the theological dimension of politically relevant concepts such as human dignity and human rights. His interest in political 
ethics arose from the political challenges that South Africa faced during the Apartheid years in the 1970s and 1980s and the period of political transition in 1994. Vorster's thinking was mainly shaped by classic Reformed theology, especially that of Calvin, Herman Ridderbos and Herman Bavinck, the political ethics of Dietrich Bonhoeffer and Jürgen Moltmann, the philosophic premises of Elaine Botha and the kingdomorientated approaches to theology of Schalk Duvenage, Tjaart van der Walt and Amie van Wyk. His political ethics was directed against Apartheid theology and liberation theology, which, according to Vorster, were both guilty of promoting inhumane ethical propositions. His main aim was to promote a culture of human rights discourse in South Africa. Vorster is considered as a progressive voice within the Reformed Churches of South Africa who gave direction to the Reformed Churches on important issues. He openly renounced the ideology of Apartheid as sin in the 1980s and strongly advocated the idea that the church needs to be open for people of all races. He also played an important role in the unification between Synod Potchefstroom and Synod Midlands, opposed the exclusion of women from the offices in the Reformed Churches of South Africa and continuously emphasised the need for churches to participate in the creation of a culture of human rights in South Africa.

A study of Vorster's political-theological ethical thinking is relevant for two reasons. Firstly, his thinking developed against the background of the political oppressive system of Apartheid and the political transition in South Africa. His views on human dignity and human rights therefore emanates not only from theoretical reflection, but also from a personal encounter with totalitarian thinking. Secondly, he is a member of the White Afrikaner minority group in South Africa, a group which bears the full impact of Black nationalism and is the object of a political process of reverse discrimination through the application of affirmative action. This experience led to certain nuances in his thinking on political-theological ethics that are of importance.

Vorster's political ethical thinking will be discussed from a thematic rather than progressive historical perspective. However, the historical development of his thought on each theme will be taken into account. As such, this article will first discuss his epistemological approach to ethics, followed by his views on Apartheid and the 'struggle' in the 1970s and 1980s, before examining the main motives in his political thinking.

\section{Epistemology}

Vorster wrote relatively little about epistemology and hermeneutics. The clearest explication of his epistemological views is found in his 2007 book, Christian attitude in the South African liberal democracy. The epistemological theory that he presents therein corresponds, to a large degree, with the methods he followed in his ethical reflection on human dignity and human rights through the years. According to Vorster, ethics studies the conduct of humans, which includes their attitude and the consequences of their actions.
It then prescribes norms in order to build a certain ethos in a community. Ethics is therefore both descriptive and prescriptive. In its prescriptive function ethics can never be neutral, because underlying the moral prescriptions will always be a philosophical, religious or ideological paradigms (Vorster 2007:2). All ethical norms flow from an ethical theory which, in turn, is determined by a certain worldview that depends on ideology, religion or belief. Vorster aligns himself with the traditional understanding of Christian ethics as presupposing a worldview, where the existence of the living God as Creator God and Redeemer God, the renewal of the world in Christ, the dynamic work of the Spirit and the acceptance of Scripture as normative for life are seen as cornerstones. Christian ethics flows from the revelation of God. In his acts in nature and history and especially in his self-revealing Word, God laid down the deepest principles for moral conduct. He also created a sense of morality in every human being and enriches this gift with the moral teachings of Scripture (2007:3).

Having said this, it is important that the ethicist's study of Scripture should be accompanied by a responsible hermeneutical approach to Scripture. Vorster rejects the critical notion that Scripture is a mere historical document or human product, because this necessarily leads to a reduction of the Christian message to a set of core values according to the life of the historical Jesus (Vorster 2007:4). In Vorster's thought, Christian ethics can never be separated from the core of the Gospel. The historical events of the cross, death, resurrection and ascension of Christ are foundational for a true Christian ethics. These events provide the indicative for the imperatives of Christian ethics. Without its foundational indicatives, Christian ethical reflection will lose its force. On the other hand, Vorster also rejects a biblicistic literalism because it leads to a form of ethical absolutism, the most poignant example of which is fundamentalism. In his book The challenge of contemporary religious fundamentalism, Vorster (2008) typifies the psychology of fundamentalism as an insider-outsider attitude, which leads to a distinction between groups that are superior and inferior. If fundamentalist groups attain power, social stratification and even violence can occur (cf. Vorster 2008:22-23).

To avoid ethical absolutism, Scripture ought to be interpreted with due regard for its textual genre, the cultural-historical context and revelation-historical context. Not all biblicalethical instructions, specifically the Old Testament notions on capital punishment, the subordination of women, the theocratical foundation of the state and human domination over the environment, can be considered as normative for a contemporary society. These instructions must be interpreted in the light of the main themes of Scripture (Vorster 2007:4).

Even though Scripture was not written in a linear historical way, contains repetitive stories and sometimes deals with issues in conflicting ways, the main message of Scripture is clear and harmonious. Scripture does not present an historical survey; it is written for various audiences and approaches certain topics from various angles. Yet, when the 
parts are seen in relation to the whole, the main message of Scripture becomes clear (Vorster 2007:6). Vorster (ibid. 2007:6) uses the term 'scope of the whole' in order to explain the divine authority of Scripture, for it is a developing organism containing a basic message by way of various sub-themes. This basic message is not a chronological story but a story in a 'revelation-historical sense'. The history of revelation is the story of the unfolding of creation, renewal and the present and future consummation of God's kingdom (ibid. 2007:6). The interpreter must therefore be cautious not to derive ethical principles from biblical parts without consulting the whole message of Scripture. For instance, one cannot conclude on the basis of Genesis 9:6 that capital punishment is justified. The verse must be read within the context of the New Testament's message of love, forgiveness and repentance, as well as other parts of Scripture that deals with the subject. Furthermore, it is important that the interpreter should distinguish between descriptive and prescriptive parts in Scripture. The mere fact that the Israelites possessed slaves does not serve as a justification for slavery, nor does Scripture's description of the existence of various nations serve as a justification for Apartheid (2007:8-9).

After discussing hermeneutical theory, Vorster reflects upon a biblical ethical theory, specifically the nature of norms. According to Vorster, a norm indicates how decisions and choices should be made; although, he rejects the notion that norms can only be derived from Scripture. It is fair to speak about revealed norms, but then the norms revealed by God's revelation not only in Scripture, but also in nature and history. There is, however, one caveat: the norms derived from God's revelation in nature and history may not be inconsistent or in conflict with the norms revealed in Scripture (Vorster 2007:10). Furthermore, Vorster distinguishes between revealed norms that he calls principles, which are valid for all times and situations, and concrete norms or rules, which are the guidelines created by the application of the principles in certain situations. Principles include the commandment of love, obedience to God, justice, respect for human dignity and life. In contrast, rules are more specific to contexts and more restricted in scope. Principles do not change; norms can change from place to place, from time to time (2007:10-11). This distinction between principle and rule, on the one hand, safeguards ethics from degenerating into a kind of relative contextualism, but, on the other hand, ensures that the contextual setting is always kept in mind.

In sum, Vorster's ethical theory can be described as revelational and deontological in nature, with the term 'revelational' meaning that God's self-revelation is the source of ethics. This 'self-revelation' though is not limited to the revelation in Scripture, but is a more comprehensive term that includes God's revelation in nature and history. Thus, norms can also be derived from rational reflection and scientific endeavour, as long as those norms are not in conflict with the central message in Scripture. When Vorster speaks about human rights, he has no qualms to ground human rights in natural law. Vorster's (2007:11) ethics is 'deontological' in that he sees actions as right or wrong in terms of their adherence to fixed principles. He firmly rejects a consequentalist approach that judges the rightness or wrongness of actions on their consequence rather than intrinsic features.

Vorster's comprehensive revelational approach is a welcome corrective to the biblicistic proof text method that is followed in some Reformed circles. Biblicistic ethics tend to become absolutist because the relationship between parts of Scripture is not evaluated; the Bible is treated as if it provides a systematic ethical system and the importance of mediation in the process of interpretation is not acknowledged. Vorster's recognition of the importance of rationality is also important because Scripture does not provide decisive answers on all ethical issues, even if an ethical dilemma is approached in terms of the main message of Scripture. Vorster's option for a deontological ethics, in contrast, might be a bit limited. Is the only purpose of ethics to ascertain what is right and what is wrong? Should ethics not also encourage virtue and the formation of character? Indeed, although Vorster's writings on practical ethics issues exhibit a concern for character formation, his epistemological theory does not reflect this.

\section{Apartheid and the 'struggle'}

Vorster's (cf. 1977:42-52) political ethical thinking was, and still is, mainly influenced by the concept of the kingdom of God which relativises the human exercise of worldly power. The Church, as a visible instrument of God's kingdom, has a prophetic duty to preach the sovereignty of God to all other spheres of life (1977:74). As a result, Vorster's approach towards both Apartheid and the 'struggle' of the 1970s and 1980s was characterised by ideological criticism. Neither Apartheid nor the notion of a 'violent struggle' was acceptable in his view. Instead, South Africans need to free themselves from the prison of ideological thinking (cf. Vorster 1991:65). Vorster believed that social change and a peaceful new dispensation could only be brought about from within, through the gospel not the fist, through negotiations not violence, through a change of heart not violent revolution, through a peaceful replacement of structures not cosmetic change.

\section{Vorster's view of Apartheid}

In his doctoral dissertation, Die kerk en die kleurvraagstuk vandag, Vorster (1977) attempted to analyse the nature of the racial conflict in South Africa. He accused the World Council of Churches and the Reformed Church in the Netherlands of interpreting the racial conflict in South Africa from a typical 1960 s and 1970s revolutionary ideological perspective, which, in turn, led to their support for the dismantling of Apartheid through violence.

In Die kerk en die kleurvraagstuk vandag, Vorster (1977) ascribes the racial conflict in South Africa to social-political, cultural, juridical and religious factors. From a social-political perspective, the racial conflict in South Africa could be described as a class struggle. The colonists came to South Africa strictly for economic purposes. They considered 
themselves as superior to other races because of their descent and state of development. Because non-White people's vast majority in numbers would give them political power in a democratic system, the colonists limited the social and economic rights of non-White people in order to protect their own economic interests and political power. This, according to Vorster (1977:31), would have far-reaching implications. Culturally speaking, the ongoing system of deculturisation was a major source of conflict. In order to subject Black people to White paternalism, to include them in a Western sociopolitical system, and to utilise them in industrial structures, the colonists had to subject Black people to Western values and emancipate them from African worldviews and traditions (1977:33). This process of deculturisation uprooted non-White people and caused them to struggle for the maintenance of their cultural identity (1977:34). A third major cause for racial conflict, according to Vorster, was the difference between Western and indigenous judicial systems, as based on different value systems. Some examples are the differences in view on private property, marriages, the status of women and the authority of tribal leaders (1977:35). Lastly, religion is a divisive factor in racial relations. Although missionaries brought many benefits to South Africa, they also attempted to impose European culture upon the indigenous people. This led to a resistance amongst Black people against what they saw as 'White Christianity'.

In Die kerk en die kleurvraagstuk vandag, Vorster (1977) rejects the notion of 'race'. There exists no such thing as a nation who can claim that they are totally communal in descent or that they are superior to other nations because of their descent (1977:26). Therefore, any racial political ideology is based upon a myth. He also rejects the notion of a Volkskerk [Peoples Church]. The people of God are the elect who belong to different ethnicities, but are unified through faith in Christ. The Church therefore transcends ethnic differences, yet it does not obliterate ethnic descent (1977:62).

In the multi-authored publication Altyd Reformeer, Vorster (1985a, 1985b) put forward his view that change could ultimately only come from within the political system. In his first contribution to this work, entitled 'Kerk en politiek', Vorster (1985a:113) calls upon White voters to use their voting rights in such a way that they ensure a dispensation can be created that safeguards the political rights of all people. This is important because the protection of all rights is ultimately dependent upon the protection of political rights. A Christian who supports a political system that withholds rights from certain groups of people acts contrary to the principle of justice (1985a:113). He then states that it is important that the Church spells out what the practical implications of justice are and that it does not refrain from doing this out of a fear for resistance (1985a:113). Political change is necessary because Apartheid is ethically not defendable and practically not viable. However, the Church must understand that change will cause fear and anxiety amongst White people. Churches must therefore educate their members to understand the need for change and repentance from a biblical perspective (1985a:114). White Christians can have no peace as long as there are others who are doomed to poverty because of an unjust political system. They must therefore be called to a political repentance and political self-denial that will comply with the biblical principles of justice, love and order (1985a:114).

In his second contribution to the above-named book, entitled 'Die Christen in gesprek met die toekoms van Suid-Afrika', Vorster (1985b) expresses concern about White and Black nationalism, but especially White nationalism. Although nationalism in itself is not necessarily unethical, it becomes a tool of oppression when it is nourished by political power. History teaches us that the ideal for a separate existence could easily degenerate into a 'non existence' (1985b:182). He then proceeds to ask the question of whether nationalist ideology in South Africa is not, in fact, blatant racism that is justified and propagated in a sophisticated modern form (ibid.). According to Vorster, South Africans will have to come to terms with pluralism. There are only two options: either South Africans will co-exist in a plural society which recognises and tolerates diversity and mutual rights, or all groups in South Africa will find their demise through racial conflict (ibid.). He concludes by saying that White people must realise: laws that impoverish people, uproot families, denies freedom of speech and inhibit opportunities for groups of people cannot withstand the biblical test of justice. Repentance is needed, but repentance is not only a personal exercise. Christians cannot claim to be repentant, but at the same still enjoy the fruits of an exploitative system. They must realise that structural sin demands structural repentance and change; however, this change must not occur through violence, but through peaceful endeavours (1985b:182-183).

In a contribution to the book Geroep tot eenheid, entitled 'Ons gemeenskaplike roeping as kerke in Suid-Afrika vandag', Vorster (1990) specifically addresses Apartheid laws such as the Population Registration Act (Union of South Africa 1950a) and Group Areas Act (Union of South Africa 1950b). He asks whether it could be considered just to persist with laws that divide South Africa into races combined with an unequal distribution of benefits and riches. He then proceeds to stress the need for a Bill of Human Rights which will guarantee the rights of all individuals in South Africa. Human rights, according to Vorster (1990:76-77), is not a mere secular concept, but is embedded in God's order for creation.

In November 1991, Koos Vorster participated in the historic Rustenburg Conference, despite heavy resistance against his participation from within the Reformed Churches in South Africa. This Conference was attended by 230 church leaders from 80 denominations and 40 para-church organisations. They met in an attempt to work towards a unified Christian witness in a changing South Africa. The result of the Conference was the 'Rustenburg declaration' (Alberts \& Chikane 1991:275), which condemned the system of Apartheid and confessed sins of the past. In his paper, which was later published in the book The road to Rustenburg, Vorster (1991) states that churches in South Africa have - up 
to then - been part of the problem not of a solution. The main reason is that churches could not reach a consensus amongst themselves on the issue of Apartheid. Although Afrikaansspeaking churches reject racism as a mental attitude, they still organise their churches on a racial basis (Vorster 1991:63). This Church Apartheid leads to an insufficient experience of spiritual communion between White and Black Christians. The unfamiliarity of White people with the living conditions of Black people is one of the important reasons for a resistance against change amongst White people (Vorster 1991:64). Black and English-speaking churches have played an important role in exposing the extent and effects of structural violence. An inherently violent structure, indeed, cannot be changed cosmetically, but must be replaced (Vorster 1991:64). However, although these churches rightly criticised the South African government for structural violence, they failed to reject the violence of terrorism, but, in fact gave this form of violence a 'clerical garb'. They thereby contributed to the emergence of a culture of violence which plagues the country and inhibit change (Vorster 1991:65). In a sense, all churches in South are prisoners of ideologies. As long as they remain captives of nationalist theology on the one hand and liberation theology on the other, they will remain part of the problem (ibid.:65). Instead, churches must seek, through ecumenical contact, to overcome their one-sided approaches and communally try to understand the message of the bible and the task of the Church in the South African situation (ibid.:65).

Vorster (1991) then proceeds to define a short-term agenda for the Church going forward. Firstly, churches must openly denounce the cycle of violence in South Africa because all forms of violence contradict the basic message of Scripture. Secondly, churches should nurture a spirit of dialogue between South Africans. Thirdly, churches ought to promote the establishment of a Bill of Human Rights because such a Bill will enable churches to realise the principles of the Kingdom of God with regard to social and political life. By way of unified testimony, churches can get involved in the formulation of such an agenda (1991:67-68). After expounding a short-term agenda, he then elaborates on a possible long-term agenda for South Africa, central to which would be for churches to address the problem of immense poverty and to help promote a culture of human rights amongst South Africans in order to prevent a repetition of the injustices of the past (1991:68-69). Indeed, Vorster would serve this agenda himself through the rest of his career through his own research and by establishing a research programme in human rights at the Theological Faculty of the North-West University.

\section{Vorster's view of the struggle}

As noted earlier, Vorster's view during the Apartheid years was that South Africa was imprisoned in ideological thinking. Not only did he reject Apartheid, but he was also highly critical of South African liberation theology and its justification of reactionary violence. In fact, Vorster believed that the violent struggle of the ANC and other liberation groups in South Africa inhibited reform, because it created a sense of fear amongst White South Africans and played into the hands of conservatives who warned about the Swart Gevaar [Black Danger].

His first doctoral dissertation (1977) was dismissive of genitive political theologies such as Black theology, revolution theology and liberation theology. According to Vorster, the abovementioned political theologies have one feature in common in that they preach a change in social relations and social structures. They can therefore be typified as theologies of change. According to Vorster, these theologies created a theological climate which he considered as indirectly responsible for the radical approach of especially the World Council of Churches (WCC) to the South African racial conflict. Vorster's main criticism against these theologies was that they uncritically translated contemporary philosophical ideas into a theological system in order to gain social relevance (cf. 1977:371-372). They are also reductionist because they use one main principle as premise and then build a whole theology around this one principle (1977:383). Often, these theologies degenerate into immanentism and anti-methaphysism. Although change is part and parcel of being Christian, the theologies of change exhibit a certain one-sidedness in their emphasis on immanence, their understanding of Western social structures as repressive one-dimensional structures and their justification of liberation from repressive structures through violence (cf. 1977:369-423).

Vorster also criticises the WCC and the Reformed Church in the Netherland's doctrine on the church. The WCC does not make a sufficient distinction between the kingdom, the institutional church and other societal spheres. Because the church is basically identified with the kingdom of God, functions of other societal spheres are transferred to the church, and the exclusive nature of the church is jeopardised. The prophetic - critical stance that the church ought to maintain, makes way for an activist approach that uses the church as a political tool in the effort to enforce revolutionary change. No limits are placed on the means that the church may use, with the result that violence is condoned as a legitimate means to impose change (cf. 1977:211, 316-317).

In 1981, Vorster published an essay entitled Die kruis of die vuis?, in which he pleaded for change through the spread of the Gospel, not revolutionary violence. He strongly criticised the Christian Institute and the South African Council of Churches for their increasing radical stances and accused them of legitimising violence, promoting civil disobedience, romanticising terrorism, and misusing the church to enforce political change (cf. Vorster 1981:25). Underlying their approaches to the South African situation was a one-sided theology, an uncritical use of Marxist philosophical theories and a questionable understanding of the nature of the church (1981:81). The fist of violence is a threat for the kingdom of God. Instead, Vorster pleads for a truly prophetic approach in accordance with the gospel of Christ (1981:34). Contact and dialogue between White and Black people is the only means 
to overcome aggression, distrust and violence (1981:34). This dialogue must be accompanied by visible and concrete priestly service. White churches will have to get involved in Black communities to alleviate poverty.

Vorster's (1984) second doctoral dissertation was a reformed apologetic study on the neo-Marxist political theology in South Africa. In this dissertation, he analysed the historic origins of liberation theology, the influence that neo-Marxist political theology exercised in South Africa through The Christian Institute and the South African Council of Churches, and the theological content of neo-Marxist political theology. He commends liberation theologians for highlighting the social injustices in South Africa and other parts of the world and for emphasising the social calling of the church (1984:167). Yet, he rejects the theology of this movement because of its secular view of Scripture, its fusion of Scriptural motives with Marxist-ideological theories, its immanent and horizontalistic understandings of the kingdom of God, the church, salvation and Christian life, its portrayal of Christ as a freedom fighter and, above all, its legitimisation of violence as a means to enforce change (cf. Vorster 1984:166-167). In Vorster's view, neo-Marxist political theology is not an authentic form of Christian theology.

\section{Evaluation}

Vorster's objective prophetical stance towards Apartheid and the 'struggle' did not make him any friends. AntiApartheid theologians, such as Frank Chikane, accused him of actually enhancing Apartheid by criticising the methods that the 'struggle' movement and institutions such as the Christian Institute and South African Council of Churches used. Apartheid ideologues, especially within the Reformed Churches of South Africa, branded him as a 'liberal' and accused him of politicising the Church. According to Vorster's opponents, the Church ought not to get involved in politics, but must restrict itself to ecclesial matters. Several complaints were lodged against Vorster throughout his career from within the Reformed Churches of South Africa, most notably a complaint against his participation in the opening of the Conference for a Democratic South Africa (CODESA) with prayer. However, he succeeded in surviving these complaints, largely because of support from other reform-minded thinkers in the church.

Vorster's prophetical critical stance on Apartheid and the 'struggle' must be appreciated, because he attempted to instil a truly Christian response to the political problems that South Africa faced. His consistent rejection of violence as a legitimate means to attain political ends was indeed important. He also played an important role within the Reformed Churches of South Africa to change racist political attitudes and to encourage dialogue between White and Black Reformed Christians. Yet, in retrospect, the question must be asked of whether Vorster's approach to Apartheid, especially in the 1970s, was dismissive enough. Although Vorster never supported Apartheid because of its discriminative nature, it seems as if he only realised the true extent of the repressive nature of the Apartheid system during the 1980s when he came into direct contact with Black Christians. This might explain why his earlier efforts were largely aimed at the violent nature of the 'struggle', whilst his later efforts concentrated more on the unjust nature of Apartheid.

\section{Political ethics}

After the political transition in 1994, Vorster directed his attentions to the creation of an ethos of human rights in South Africa. His writings would focus on variety of issues related to political ethics issues such as human dignity, gender, racism and xenophobia, land reform, religious freedom, HIV and AIDS, economic freedom, Christian attitude in a liberal democracy, and fundamentalism. The nature of this article does not allow a discussion on all of these themes. Instead the main motives in his political-ethical thinking will henceforth be discussed.

\section{Human dignity and human rights}

Vorster (2008:197) is of the opinion that there is a deepseated difference between the Christian and liberal-humanist understanding of human dignity. This necessarily will lead to different interpretations and applications of human rights. He grounds the concept of human dignity in various biblical themes. First of all, human dignity is a status that God awards the human being by creating him as imago Dei. The imago Dei is primarily a theological concept, but has extensive anthropological and social-ethical implications, because it is a relational concept that relates the human being to God, fellow human beings and the environment. By exhibiting humaneness, human beings reflect the virtues of God. The imago Dei reveals that human beings are representatives and partners of God and therefore endowed with an inherent dignity. Their dignity is not seated in their inherent rational capabilities or autonomy as the liberal tradition would argue, but in the status that God grants them (2008:199). All human beings possess human dignity, because all human beings are created in the image of God. Although sin deforms the human being it does not obliterate the imago Dei, because God upholds the dignity of the human being despite sin (2008:197).

A second theological theme of importance for human dignity is that the human being receives God's spirit and creational gifts (Vorster 2008:199). In Genesis 2:7, God confers his nefesj to the human being, which not only refers to biological life but, within the specific theological context, symbolises the uniqueness of the human being. Something of God's own self becomes an integral part of human identity (2008:199). God bestows all human beings with creational gifts such as a natural religiosity, a sense of justice, artistic capacities, inner goodness, the ability to love and other qualities. These creational gifts are part of God's general grace and must be distinguished from spiritual gifts such as faith. The fact that all human beings receive creational gifts, and that these gifts are not obliterated by sin, is of special importance for a Christian anthropology. Whereas all human beings receive creational gifts, God grants his recreational gifts to humanity in a 
generic sense, but not to all individual members. Humanity is generically represented in the new humanity of Christ and therefore participates in the imago Christi (2008:200). Through his Spirit, Christ repairs the original image of the faithful to the likeness of God.

A third important theological theme is that the human being is appointed as the custodian of God's creation (Vorster 2008:201). God entrusts his creation to humans. This does not imply a right to exploitation and self-enrichment, but entails a responsibility to care for creation and to be instrumental in the unfolding of God's purpose with creation. The human notion towards dominating depicts the nature of human dignity. Humans possess a human dignity, but not a divine dignity. His dignity can never be absolute, because humans cannot replace God or be God. His dignity is always a gift not an inherent characteristic. Because dignity is a status that God grants human beings, humans have to act in accordance with this status through a dignified and holy life that glorifies God (2008:201-202).

Lastly, Vorster (2008:202) grounds dignity in the fact that humanity, although not all its individual members, inherits the new earth. This inheritance is the result of God liberating humanity from its slavery to sin and adopting them as his children. Being a child of God implies a status of dignity that is inalienable. Because human beings are God's instruments in effecting the coming of the new earth, dignified human labour is a calling that is part of the renewal of God's creation.

Clearly Vorster has a very comprehensive understanding of human dignity. In contrast to the liberal-humanist view, dignity is not a mere description of the essential inalienable characteristics of the human, but a status that God grants humans and which ought to direct their ethical behaviour. Human dignity is therefore not only the source from which human rights proceed, but also a moral category that demands responsible and dignified behaviour. This definition of dignity as both a status and moral category enables Vorster to correlate rights with ethical duties.

What implications does a Christian view of human dignity have for human rights? According to Vorster (2008:203-204), the uniqueness of a Christian view of human rights is that it emphasises that rights should always correspond with a sense of responsibility towards fellow human beings and institutions of authority. Although duties can never be incorporated in a juridical document such as a Bill of Rights for legal reasons, it is important to promote an ethos of responsibility amongst the citizenry (cf. Vorster 2004:88-90). This sense of duty is especially important in a poor society such as South Africa which is plagued by the HIV and AIDS pandemic and poverty. A Christian approach will always take socio-economic rights and environmental rights very seriously and will not accept the materialistic neo-liberal economical discourse uncritically (Vorster 2008:203-204). In contrast to the liberal discourse on rights, which takes its premise in the autonomy of the individual, a Christian view will not recognise a right to abortion or euthanasia because life belongs to God and is therefore inalienable (Vorster 2008:203).

With regard to human rights, Vorster (2004:88-90) is of the opinion that this concept must be clearly defined to avoid misconceptions. He distinguishes between human rights in a legal-moral sense and human rights in an ethical sense. Rights that are legally enforceable ought to be defined as fundamental rights. Fundamental rights are never purely objective universal rights, but have to be contextualised within the circumstances and in the light of the history of a particular political community (2004:89). Although fundamental rights serve a legal purpose, they do have an ethical dimension, because they are founded in moral systems, they create moral value systems and they require ethical reflection when some enshrined rights come into moral conflict with others (cf. Vorster 2004:1-3). Human rights in an ethical sense are public ideals that are not necessarily legally enforceable. They rather pertain to a particular ethos in a society that must be developed according to certain principles (2004:90). Here, the contributions of ethicists are of particular importance.

In both Ethical perspectives on human rights and Christian attitude in the South African liberal democracy, Vorster (2004, 2007) attempts to promote ethical principles that might instil a culture of human rights in South Africa. He addresses a wide range of themes which cannot be discussed in this article; however, certain primary motifs on rights topics recur in these books. Firstly, Vorster (2007:2) is of the opinion that ethics is closely intertwined with attitude. Attitude is shaped by our deepest beliefs. It is a human way of thinking and behaving and determines the cause of thinking, of formulating principles and norms and of projecting ideals and hope. Conversely, attitude determines the way of living, of forming relations, of engaging in science and culture, of doing politics and economics and of fulfilling a daily task. The attitude of a Christian should, according to Vorster (cf. 2007:viii), be an embodiment of the attitude of Christ which is deeply rooted in his redemptive and renewing work and which unfolds in the noble principles of love, self-denial, stewardship and obedience to God.

Secondly, Vorster's (2004:67-83) political ethics can certainly be described as Christian 'humanist' in nature. Humaneness is a key and recurring theme in his social ethics. His writings consistently attempt to expose the ideological fallacies that underlie systems and practices such as racism and xenophobia, gender discrimination, neo-liberalist capitalism, fundamentalism, religious repression, ecocide and discrimination against minorities. Conversely, he attempts to contribute to a more humane society by addressing themes such as the right to life, the promotion of an ethos of human rights, the fight against poverty and HIV and AIDS, protecting the most vulnerable, transformation and truth and reconciliation in South Africa. He places quite a lot of emphasis in his ethics on the importance of 'life' as a guide for ethical behaviour. One of the main characteristics of the acts of God is that he creates and nurtures life. The creation narratives emphasise that God brought life in a 
totally inhospitable universe. This life-giving virtue of God is mirrored in the imago Dei that entails, inter alia, that humans must nurture and conserve the life that God has created. The recreational work of God entails redemption and spiritual regeneration through the Spirit. Life in a recreational sense emphasises the need for Christian love as a guideline for ethical behaviour. God's creation is on its way to the fullness of time and eternal life which brings hope for humankind and expectation.

Thirdly, Vorster's social ethics is strongly informed by a form of creational theology. He believes in the existence of divinely created societal spheres, each with its own immanent norms that need to be positivised by human beings. As long as the state respects the sovereignty and immanent norms of each sphere, society will function freely and cohesively. In Vorster's (cf. 2004:230) view, the most basic divine institutions are marriage and the state. That is why he is highly critical of same-sex marriages and the overthrowing of governments through violence. Although his ethics exhibits some characteristics of neo-Calvinist thinking, he cannot be typified as a neo-Calvinist in the strict sense of the word. His social ethics is less rigid than the societal doctrine of neoCalvinist philosophy, especially with regard to his view of the church. The Church is, in Vorster's thinking, not merely an institution that administers the Word and Sacraments, but is an instrument of God's kingdom in society and therefore needs to engage with society.

Fourthly, Vorster can be typified as a social democrat who stresses the importance of socio-economic and ecological rights. His social democratic views ought to be understood within the South African economic context of endemic poverty and a high unemployment rate. Although he has a high regard for freedom, freedom should not be exercised without due respect for responsibility. Political practices must serve the overall social cohesion of a society. Since the 1970s, he has consistently argued that poverty is South Africa's biggest challenge and that the development of skills, job creation programmes and other initiatives are of utmost importance. He believes that in conditions of abject poverty the state has a role to play in development and that an economy strictly based upon neo-liberalist principles cannot address the challenges of a developing country but will actually widen the gap between rich and poor.

Lastly, the concept of the kingdom informs his social ethics decisively. The kingdom of God signifies, according to Vorster (cf. 1996:27-39, 2007:253), the establishment, recognition and eventual vindication of God's reign. This reign is characterised by justice, love, joy, peace, forgiveness and reconciliation (Vorster 2007:253). Vorster views the kingdom of God as the point of orientation for a truly Christian social ethics. All spheres of society are subject to God's reign that relates and relativises all earthly power. No human authority can therefore possess absolute power. Because God's kingdom is a kingdom of righteousness, it is the duty of the Christian to proclaim justice in a world of injustice and of the church to preach about social justice (Vorster 1981b:33, 62-64).
He is highly critical of the Kuyperian ecclesiological model, which restricts the task of the Church as institute solely to ecclesiastical affairs. The calling of the believer may never be defined in ecclesiological terms, as was done by the Reformed Churches in South Africa during the Apartheid years, but is determined by the scope of God's kingdom which affects all spheres of life (Vorster 1996:194-195). After all, the task of the Christian is to be an instrument of social change by promoting the noble principles of God's kingdom. The church is not an end in itself, but is the proclaimer of the reign of God over all spheres of life (1996:196). It is therefore important that the Church as institute also addresses social issues (1996:93).

\section{State and religion}

One of the main challenges for the South African society in the post-1994 period was to redefine the relationship between Church and state within the context of a liberal democracy. A theocratic relationship between Church and state is not viable in a pluralistic society with many different religions. Vorster (2010) distinguishes between four different models followed in history on the relationship between Church and state, after which he proposes a fifth, alternative model. Firstly, the 'active theocratic option', is according to Vorster (2010:167), based upon a theocratic worldview. This model propagates that a country's government actively favours a specific religion, and that society at large ought to be arranged according to the principles and ethical criteria of that specific religion. Accordingly, other religions are either declared as illegal, or tolerated as long as they do not interfere or clash with the ruling religion. This model was followed in the Roman Empire and was also promulgated by the Anabaptists and Calvin in the 17th century. At present, there is a revival of this option in various Muslim countries. Where this model has been followed, religious violence, bloodshed and persecution has arisen because of this option's failure to allow or grant freedom of religion, speech and conscience. The theological problem with this option, when promoted from a Christian perspective, is that the kingdom of God is equated with an imminent political reality (2010:169). Legislation cannot shape people's morals or internalise convictions. The kingdom of God can only be served when people internalise the principles of Christ's kingdom; when people's religious convictions are restricted or inhibited it causes feelings of resentment and anger and may create violence and aggression. A truly Christian approach to other religions would be to lovingly proclaim the gospel of God without using coercive measures or methods of persuasion (2010:169-170).

The second model that Vorster (2010:170) discusses is the 'active state-religion option', which allows for contemporary rulers to single out and favour a specific religion, as is the case in the United Kingdom. It differs from the active theocratic option in that it acknowledges and protects other religions in its rule and operates without using a fundamental text as basis. Although the authority does not base its state government on the ethical principles of the favoured 
religion, freedom of religion is hampered because of unequal exposure (2010:170). The problem with this option is that certain criteria and symbols are forced on people belonging to other religions. In the United Kingdom, this option leads to Christianity being wrongly projected as an apolitical entity (2010:171).

Thirdly, the 'active neutral option' (Vorster 2010:171-172) functions in most constitutional democracies, of which the USA and France are the most well-known examples. It entails the total separation of Church and state. The government makes no religious or ideological choice and guarantees the freedom of all religions that conform to the norms of the constitution and the norms of general order and peace within the community. State and Church are seen as free to operate within their own spheres of authority. The state does not control or dominate religion or religious institutions, and religion does not prescribe state policies. Vorster (2010:173), though, asks the question of whether neutrality is possible. Constitutions and laws are always written from a particular perspective that is determined by a worldview. Neutrality cannot avoid limiting the role of religions, because when religion is replaced in the public sphere the vacuum will be filled by an ideology that the government holds dear.

Fourthly, Vorster's (2010:174-175) 'active universalist option' attempts to create a universal value system that will be acceptable to all religious people. A universally accepted view of God is developed through means of an interreligious education. The acceptability and applicability of every religion is investigated and weaved into a value system which is then promoted by the state. The problem with this is that a new form of civil religion is enforced upon society which heightens the potential for religious conflict.

Finally, Vorster (2010:177-179), instead, endorses a model which he calls the 'active plural option'. Whilst the active neutral option departs from the premise that all religions should be removed from the public sphere and only be allowed to function in the private sphere, this model allows religions to function in the public sphere. The same rights are granted to people of all religions and all religions may function in the public sphere within the confines of their principles, as long as participation in such religious practices are free and non-discriminative. The government only acts against a religion if it transgresses the law. According to Vorster (2008), this option is best because it creates 'space' for everyone and allows religions to make a useful contribution to society. He gives striking examples of the positive role that religion played in history in his book, The challenge of contemporary religious fundamentalism:

Religions were also active agents in the development of communities. Early Christianity set the tide for the improvement of the position of slaves, women and children in the Hellenistic culture. It introduced a new morality where love was emphasised as the main element of Christian conduct and promoted a more human society. The monasteries became huge centres of cultural, scientific and agricultural research. Where it became an established religion Christianity always promoted education and instituted many schools and other educational institutions. The Roman Catholic Church was throughout its history instrumental in the furthering of medical science and the establishment of hospitals and caring centers. (p. 135)

Vorster's understanding of religious freedom exhibits a true insight in the nature of religion. Religion contains the deepest beliefs of people. Precisely because they are held by religious people in such a high esteem, these beliefs can turn into violence and anger if they are repressed. For this reason, Vorster's plea for 'space' is important. Conversely, Vorster also realises that religion - specifically the Christian religion - can make a very important contribution to society. The public sphere needs religion and cannot escape religious beliefs, because there is no such thing as a neutral value system.

\section{Responsible economics}

As mentioned earlier, Vorster regards the problem of poverty as the main threat for a stable South African society. Although he supports a market-driven economy, he is adamant that corporations should be responsible moral agents because many problems could arise within such an economy. He cites the problems of mega-corporations abusing human rights by using illegal labour and child labour, polluting the environment, using cheap labour in areas with high unemployment rates and doing business with totalitarian regimes. Vorster (2007) is particularly critical of neoliberalism's notion of value neutral economics:

The corporation is part of a network and the interaction with other spheres of society creates the framework of values and ideals of the corporation. In a sense the corporation is the product and the reflection of the society it serves. Therefore the notion of a value-neutral corporation is invalid. A corporation is value-driven, and these values can be self centred. Materialist, humanist or service oriented. The question is thus not whether the corporation should have a value system or not, but whether the corporation has a sound value system. (pp. 114-117)

From a Christian-ethical perspective, he identifies four important principles for doing business. Love is the cornerstone of the Christian ethical idea of social justice, stewardship replaces self-centred service with kingdomoriented service, self-denial stands over and against selfinterest and demands that businesses also fulfil social roles by entering into non-self-interested concerns and obedience which entails that corporations cannot engage in acts of destruction.

Whereas neo-liberalism regards socio-economic rights as a vestige of socialism and as an obstruction to the marketdriven economy, Vorster (2007:124-125) propagates a society where socio-economic rights are recognised to protect the poor. After all, in a system founded upon economic competition there will always be losers. The poor tend to become poorer in capitalist societies. According to Vorster (2007:125-126), specific socio-economic rights that need to be protected are the right to a living wage and the right of access to natural resources. Vorster's concern is that business and the rigid demands of a capitalist system might determine the 
ethics of a society in the name of a market-driven economy, instead of society's values determining the way business is conducted.

Vorster's criticism on neo-liberalism is indeed valid. The market-driven economy is encroaching on all spheres of life, even education and medical services. It leads to a culture of materialism and excessive consumption and creates a culture of greed through its attempts to continuously create new markets for products. Because of the marketdriven economy's competitive nature, people with a poor background and poor education are doomed to failure; they simply cannot compete in an environment where skills are decisive for success. Yet, the question must be asked whether Vorster's notion that businesses should engage in non-profit social activities does not impinge on his own belief of a sovereignty in own sphere?

\section{Conclusion}

Vorster's academic career spanned the Apartheid and postApartheid period in South Africa's history. His ethics are, however, remarkably consistent. Throughout his career he devoted himself to the nurturing of humaneness, fighting poverty and enhancing respect for human rights. $\mathrm{He}$ consistently uncovered and rejected violence, discrimination, racism, power abuse, religious fundamentalism and economic exploitation. Vorster not only theorised about ethics, but practiced the ethics which he preached through his efforts to engage in political dialogue with Black Christians in the Apartheid years, his participation at the Rustenburg Conference and at CODESA, his ministry in poor and disadvantaged areas, and his efforts to promote women's rights in the church. Indeed, his own life exemplified the attitude of Christ. The question remains: did Vorster succeed in his efforts to promote an ethics of humaneness and an ethos of human rights in South Africa? Our suggestion is that he certainly succeeded to change ethical and anthropological thinking within the Reformed Churches of South Africa and to improve racial relations in the Church. Traditionally, the Reformed Churches in South Africa had a negative stance towards the concept of human rights. At present, studies in the ethics of human rights are - as a result of the efforts of Vorster - part of theological training of Reformed ministers. The Faculty of Theology at the North-West University also manages a flourishing project on human rights and ethics which has, thus far, produced a number of doctoral dissertations, scientific articles and books. It is of utmost importance that academia within the Reformed Churches of South Africa build upon Vorster's contribution by engaging in human rights discourse and societal issues from a Reformed premise. Although his retirement from active academic life will leave a void, we are looking forward to his future ethical contributions.

\section{Acknowledgements Competing interests}

Nico Vorster, one of authors of this paper, is the son of Koos Vorster, the theologian whose academic career and politicoethical thinking forms the subject of the discussions herein.

\section{Authors' contributions}

Both Prof. N. Vorster and Prof. J.H. van Wyk contributed to this article. Prof. J.H. van Wyk was responsible for identifying the most important sources, giving experiental inputs and revising the final product, whilst Prof. N. Vorster contributed to the writing and final editing of the article.

\section{References}

Alberts, L. \& Chikane, F. (eds.), 1991, The road to Rustenburg: The church looking forward to a new South Africa, Struik, Cape Town.

Union of South Africa, 1950a, Population Registration Act (Act No. 30 of 1950), Government Printers, Pretoria.

Union of South Africa, 1950b, Group Areas Act (Act No. 41 of 1950), Government Printers, Pretoria.

Vorster, J.M., 1977, 'Kerk en die kleurvraagstuk vandag', DPhil thesis, Department of Philosophy, Potchefstroom University for Christian Higher Education, Vorster, J.M., 1981a, Die kruis of die vuis? Kerk en rewolusie in Suid-Afrika, Van Wyk, Pretoria.

Vorster, J.M., 1981b, Het die kerk nog betekenis?, NG Kerkboekhandel, Pretoria.

Vorster, J.M., 1984, 'Die neo-Marxistiese politieke teologie in Suid-Afrika, 'n Gereformeerd-apologetiese studie', ThD thesis, Department of Theology, Potchefstroom University for Christian Higher Education.

Vorster, J.M., 1985a, 'Kerk en politiek' in J.H. van Wyk \& J.M. Vorster (eds.), Altyd reformeer, Gesprekke oor politiek en godsdiens, pp. 100-119, Boekhandel De Jong, Braamfontein.

Vorster, J.M., 1985b, 'Die Christen in gesprek met die toekoms van Suid-Afrika', in J.H. van Wyk \& J.M. Vorster (eds.), Altyd reformeer, Gesprekke oor politiek en godsdiens, pp. 180-183, Boekhandel De Jong, Braamfontein.

Vorster, J.M., 1990, 'Ons gemeenskaplike roeping as kerke in Suid-Afrika vandag, in H. Du Toit \& P. Kruger (eds.), Geroep tot eenheid, pp. 74-83, NG Kerkboekhandel, Halfway House.

Vorster, J.M., 1991, 'Understanding the South African reality', in L. Alberts \& F. Chikane (eds.), The road to Rustenburg: The church looking forward to a new South Africa, pp. 62-72, Struik, Cape Town.

Vorster, J.M., 1996, Is die kerk funksioneel? Gedagtes oor gereformeerde kerkvernuwing in 'n postmoderne konteks, Potchefstroom Theological Publications, Potchefstroom.

Vorster, J.M., 2004, Ethical perspectives on human rights, Potchefstroom Theological Publications, Potchefstroom.

Vorster, J.M., 2007, Christian attitude in the South African liberal democracy, Potchefstroom Theological Publications, Potchefstroom.

Vorster, J.M., 2008, The challenge of contemporary religious fundamentalism, University of South Africa, Pretoria.

Vorster, J.M., 2010, 'Current options for the constitutional implementation of religious freedom', in A. Van De Beek, E.A.J.G. Van der Borght \& B.P. Vermeulen (eds.) Freedom of religion, pp. 155-181, Brill, Leiden. http://dx.doi.org/10.1163/ ej.9789004158078.i-269.66 